\title{
Teaching Motivation: The Kung Fu Panda way
}

\author{
Surabhi Singhal \\ Ramjas College, University of Delhi, INDIA \\ Email id: surabhisinghal@ ramjas.du.ac.in
}

\begin{abstract}
The widely acclaimed animated movie, Kung Fu Panda, provides an interesting resource for teaching concepts of motivation including Intrinsic and Extrinsic Motivation, Self-efficacy, Self-fulfilling Prophecy and Vroom's Expectancy Theory. This article provides clip-by-clip examples that exhibit these concepts along with discussion prompts and probable answers that facilitate engagement and understanding among students. Time stamps of clips have been provided which students are expected to watch and prepare reflection notes prior to the lecture. In-class discussions among students based on their reflection notes prove effective in analysing and learning the interwoven concepts and their application in true sense.
\end{abstract}

KEYWORDS: extrinsic motivation, intrinsic motivation, self-efficacy, self-fulfilling prophecy, teaching through movie clips, Vroom's expectancy theory, work motivation

\section{INTRODUCTION}

Kung Fu Panda (Stevenson \& Osborne, 2008), an animated movie with anthropomorphic animals, provides an interesting resource for teaching motivation concepts through engaging classroom discussions. This movie has been highly acclaimed and nominated for the Academy Award for Best Animated Feature Film as well as numerous Annie Awards in the year 2009 (Kung Fu Panda Awards, n.d.). In this article, the movie has been used to teach the concepts of Intrinsic and Extrinsic Motivation, Self-efficacy, Self-fulfilling Prophecy and Vroom's Expectancy theory; which students often find difficult to understand during lectures.

\section{RESOURCE DESCRIPTION}

The movie is set in a fantasy land called the Valley of Peace in ancient China where the protagonist, a big panda named Po, unwittingly gets chosen as the prophesied Dragon Warrior, a Kung Fu legend who is responsible for the safety of the valley. The story revolves around how Master Shifu transforms Po from a state of low to high motivation and trains him in Kung Fu to become a worthy Dragon Warrior. Table 1 shows the key characters in the movie.
The movie begins with Po dreaming of being a Kung Fu warrior and fighting alongside the Furious Five but wakes up to work in his father's restaurant serving noodles and soup. Po is obsessed with Kung $\mathrm{Fu}$ and treats the Furious Five as his idols. However, his father, Mr. Ping wants him to take interest in the restaurant. Po works in his father's restaurant and keeps his deep desire to learn Kung Fu a secret.

Meanwhile, Master Oogway informs Shifu about his vision and predicts that the notorious Tai Lung will escape from prison and attack the valley to obtain the Dragon Scroll, a document that could give limitless power to its holder. Shifu hurriedly announces a tournament so Oogway can identify the Dragon Warrior. Po gets super excited to watch the performance of the Furious Five, the contenders for the title, but arrives too late to enter the arena. Desperate to see his idols, Po accidentally launches himself into the arena and lands in front of Oogway's finger, supposedly meant to point at the chosen one. Oogway, to the bewilderment of everyone, names Po the Dragon Warrior. 
Table 1. Key Characters in the Movie

\begin{tabular}{ll}
\hline Po & $\begin{array}{l}\text { A big panda who dreams of Kung Fu but works } \\
\text { at his adoptive father's restaurant (voiced by } \\
\text { Jack Black). }\end{array}$ \\
$\begin{array}{l}\text { Master } \\
\text { Shifu }\end{array}$ & $\begin{array}{l}\text { A red panda, the trainer of the Furious Five } \\
\text { (voiced by Dustin Hoffman). }\end{array}$ \\
Master & $\begin{array}{l}\text { An elderly tortoise, the wise grandmaster, } \\
\text { Shifu's mentor and creator of Kung Fu (voiced } \\
\text { by Randall Duk Kim). }\end{array}$ \\
Furious & $\begin{array}{l}\text { A group of a Tigress (voiced by Angelina Jolie), } \\
\text { a Viper (voiced by Lucy Liu), a Monkey (voiced } \\
\text { by Jackie Chan), a Mantis (voiced by Seth } \\
\text { Rogen), and a Crane (voiced by David Cross), } \\
\text { the five masters who are considered as the } \\
\text { most skilled warriors in China. }\end{array}$ \\
& $\begin{array}{l}\text { A snow leopard, the antagonist with } \\
\text { supernatural strength (voiced by Ian McShane). }\end{array}$ \\
Tai Lung & $\begin{array}{l}\text { A Chinese goose, the adoptive father of Po who } \\
\text { runs a restaurant (voiced by James Hong). }\end{array}$ \\
Mr. Ping &
\end{tabular}

Shifu considers Oogway's decision as an accident and tries to get rid of Po with a harsh training schedule. The Furious Five reject Po as a fanatic with no prospects. Po gets disheartened and plans to quit. Oogway identifies that Po is upset and encourages him to focus on the present and forget about the past or the future. Thereafter, Po continues his training and slowly befriends the Furious Five with his resilience, cooking skill, and humour. Meanwhile, as predicted, Tai Lung manages to escape from prison.

Shifu informs Oogway about the escape. Oogway takes a promise from Shifu to believe in Po and leaves this mortal world for his time has come. As promised, Shifu starts to believe in Po and promises him to train a worthy Dragon Warrior. When Po asks how Shifu will train him, Shifu admits that he doesn't know how. The next day, Shifu finds Po eating secretly in the kitchen and performing impressive physical feats for the same. He identifies that Po gets motivated by food. Thereafter, he trains Po in an innovative way using food as a reward.

On completion of the training, Shifu decides that Po has become worthy of receiving the Dragon Scroll but gets disappointed on discovering that the scroll is blank. The scroll was simply a reflective surface that did not bestow any secret power to its holder. Considering it to be useless, Shifu decides to evacuate the valley and fight Tai Lung alone. During evacuation, Mr. Ping consoles Po over what has happened and reveals that the soup served by him in his restaurant, which is famous as his "secret ingredient soup", has no secret ingredient and explains that things are special if people believe they are. Po realizes that this was the inherent message of the Dragon Scroll as it only reflects the reader's own face. Po rushes back to help Shifu in the fight.
Meanwhile, Tai Lung beats Shifu and asks for the Dragon Scroll. Po reaches in time with the scroll and challenges Tai Lung to take it from him. Tai Lung attacks Po but gets frustrated by Po's unpredictable Kung Fu techniques. Po, finally defeats Tai Lung and gets honoured by the valley.

\section{USE IN THE CLASSROOM}

Motivation is an indispensable topic in all management courses. KungFu Panda has proven effective in teaching the concepts of Intrinsic and Extrinsic Motivation, Selfefficacy, Self-fulfilling Prophecy and Vroom's Expectancy Theory.

The Discussion Guide in Table 2 describes the clips from the movie that may be used for discussing the said concepts along with probable questions that may be posed for discussion in the classroom. Students are expected to watch the clips provided in Table 2 and prepare reflection notes prior to the lecture. The discussion questions reflect key issues and prove effective in initiating meaningful classroom discussion.

\subsection{Intrinsic motivation}

A person is said to be intrinsically motivated when they are engaged in an activity because they enjoy doing that activity itself and not for any external rewards (Ryan \& Deci, 2000). The opening scene (0:0:34 - 0:2:46) of Po's dream about Kung-Fu reflects that he is obsessed with KungFu and wants to learn it from the core of his heart. This scene may be used to create a discussion among students about whether Po is intrinsically motivated to learn Kung Fu or not.

\subsection{Need for Extrinsic Motivation}

Intrinsic motivation may get enhanced or diminished due to presence or absence of factors like competence, autonomy and relatedness (Ryan \& Deci, 2000). The next few clips highlight how intrinsic motivation may get diminished and not sufficient for achieving an objective. The present environment may result in a low motivation level despite pre-existing intrinsic motivation.

In the movie, Po is unwittingly chosen as the KungFu Warrior (0:10:13 - 0:15:35) and he is full of excitement but is not welcomed by Master Shifu (0:19:44 - 0:21:58). Shifu attempts to demotivate Po $(0: 22: 40-0: 26: 15)$ and Po gets further demotivated by his colleagues, the Furious Five (0:26:17 - 0:29:22).

\subsection{Self-Efficacy}

Self-efficacy refers to an individual's belief in their capacity to perform (Bandura, 1977) and is related to performance in a positive way (Leon-Perez et al., 2011). Employees' self-efficacies play an important role in organisational training programmes (Loomba \& Karsten, 2019).

In the next clip (0:29:57 - 0:30:37), Po loses confidence and feels that he cannot learn KungFu. He talks of quitting and returning back to his restaurant. This 
reflects Po's low self-efficacy, that is, low confidence about his ability to learn Kung Fu.

\subsection{Self-fulfilling Prophecy}

Merton (1948) coined the phrase 'Self-fulfilling Prophecy' to describe "a false definition of the situation evoking a new behavior which makes the originally false conception come true". Self-fulfilling prophecy is a sociopsychological phenomenon of expecting something and that expectation coming true simply because the person believes it will (Biggs, 2013).

In the movie, Shifu informs Master Oogway that Tai Lung has escaped from prison and is headed towards the valley. Oogway tells Shifu that Po would not be able to defeat Tai Lung unless Shifu believes in Po, the dragon warrior. Po would fulfill his destiny only if Shifu believes in it completely. Finally, Shifu promises Oogway that he will believe in Po and his destiny as a dragon warrior (0:42:32 - 0:45:12).

\subsection{Vroom's Expectancy Theory}

Vroom's Expectancy theory (Vroom, 1964) is a process theory of motivation that describes motivation as a product of three components viz. Expectancy, Instrumentality and Valence.

In the movie, when Shifu tells Po about Tai Lung's escape and that it's Po's responsibility to stop Tai Lung, Po gets afraid and tries to run away. This reflects a low expectancy resulting primarily from Po's low selfefficacy. Shifu calls for Po's trust in him and assures that he will make Po learn Kung Fu (0:47:25 - 0:50:05), thereby increasing Po's Expectancy.

In the next scene (0:51:40 - 0:53:30), Shifu hears some noises and follows them to the kitchen where he finds Po performing unimaginable feats while searching for food. Shifu identifies that Po has a high Valence for food.

Shifu identifies that he will have to train Po by making use of Po's high valence for food. Shifu tells Po, "When you have been trained, you may eat" (0:54:32 - 0:58:42). He establishes a clear relationship between Po's performance and the resulting outcome in the form of food. The result was a high level of Instrumentality.

Table 2. Discussion Guide

\begin{tabular}{llll}
\hline $\begin{array}{l}\text { Scene } \\
\text { description }\end{array}$ & $\begin{array}{l}\text { Discussion } \\
\text { questions }\end{array}$ & $\begin{array}{l}\text { Answers to } \\
\text { questions }\end{array}$ & $\begin{array}{l}\text { Time } \\
\text { marker }\end{array}$ \\
\hline Po's dream & $\begin{array}{l}\text { What is Po's } \\
\text { inner desire? }\end{array}$ & $\begin{array}{l}\text { To learn Kung } \\
\text { Fu }\end{array}$ & 0:34-2:46 \\
$\begin{array}{l}\text { Oogway } \\
\text { chooses Po as } \\
\text { the dragon } \\
\text { warrior }\end{array}$ & $\begin{array}{l}\text { What does it } \\
\text { mean for Po? }\end{array}$ & $\begin{array}{l}\text { Po gets a life- } \\
\text { time } \\
\text { opportunity } \\
\text { for what he }\end{array}$ & $\begin{array}{l}\text { 10:13- } \\
\text { always }\end{array}$ \\
& like Po? & $\begin{array}{l}\text { dreamed of. } \\
\text { No, Shifu }\end{array}$ & \\
& & $\begin{array}{l}\text { wants Po to } \\
\text { quit }\end{array}$ & \\
& & &
\end{tabular}

\begin{tabular}{|c|c|c|c|}
\hline $\begin{array}{l}\text { Po enters the } \\
\text { Jade Palace }\end{array}$ & $\begin{array}{l}\text { How is Po's } \\
\text { reaction? }\end{array}$ & $\begin{array}{l}\text { Po is excited to } \\
\text { see the palace. } \\
\text { However, he is } \\
\text { not welcome } \\
\text { by Shifu. }\end{array}$ & $\begin{array}{l}19: 44- \\
21: 58\end{array}$ \\
\hline $\begin{array}{l}\text { Attempt to } \\
\text { demotivate } \\
\text { Po }\end{array}$ & $\begin{array}{l}\text { Why does } \\
\text { everyone } \\
\text { want Po to } \\
\text { quit? }\end{array}$ & $\begin{array}{l}\text { No one } \\
\text { believes that } \\
\text { Po is fit for the } \\
\text { job. }\end{array}$ & $\begin{array}{l}22: 40- \\
26: 15\end{array}$ \\
\hline $\begin{array}{l}\text { Po talking to } \\
\text { Oogway }\end{array}$ & $\begin{array}{l}\text { Why is Po } \\
\text { demotivated? }\end{array}$ & $\begin{array}{l}\text { Po starts to } \\
\text { doubt his } \\
\text { competence } \\
\text { due to the } \\
\text { behaviour of } \\
\text { his peers and } \\
\text { his master. }\end{array}$ & $\begin{array}{l}29: 57- \\
30: 37\end{array}$ \\
\hline $\begin{array}{l}\text { Shifu informs } \\
\text { Oogway the } \\
\text { Tai Lung has } \\
\text { escaped from } \\
\text { prison }\end{array}$ & $\begin{array}{l}\text { What is } \\
\text { Oogway } \\
\text { asking Shifu } \\
\text { to do? }\end{array}$ & $\begin{array}{l}\text { To believe in } \\
\text { Po as a dragon } \\
\text { warrior. }\end{array}$ & $\begin{array}{l}42: 32- \\
45: 12\end{array}$ \\
\hline $\begin{array}{l}\text { Shifu tells Po } \\
\text { about Tai } \\
\text { Lung's escape }\end{array}$ & $\begin{array}{l}\text { Why does Po } \\
\text { run away? } \\
\text { What is Shifu } \\
\text { trying to do? }\end{array}$ & $\begin{array}{l}\text { Po does not } \\
\text { believe that he } \\
\text { has the ability } \\
\text { to stop Tai } \\
\text { Lung. } \\
\text { Shifu is } \\
\text { assuring Po } \\
\text { that he will } \\
\text { train him and } \\
\text { make him the } \\
\text { dragon } \\
\text { warrior. }\end{array}$ & $\begin{array}{l}47: 25- \\
50: 05\end{array}$ \\
\hline $\begin{array}{l}\text { Po eating in } \\
\text { kitchen }\end{array}$ & $\begin{array}{l}\text { What does } \\
\text { Shifu } \\
\text { observe? }\end{array}$ & $\begin{array}{l}\text { Po likes to eat } \\
\text { and can do } \\
\text { difficult feats } \\
\text { with ease for } \\
\text { food. }\end{array}$ & $\begin{array}{l}51: 40- \\
53: 30\end{array}$ \\
\hline $\begin{array}{l}\text { Shifu trains } \\
\text { Po }\end{array}$ & $\begin{array}{l}\text { How is Shifu } \\
\text { able to train } \\
\text { Po? }\end{array}$ & $\begin{array}{l}\text { By defining a } \\
\text { clear } \\
\text { relationship } \\
\text { between Po's } \\
\text { performance } \\
\text { and food as a } \\
\text { reward. }\end{array}$ & $\begin{array}{l}54: 32- \\
58: 42\end{array}$ \\
\hline
\end{tabular}

\section{ANALYSIS AND COMPARISON}

According to Blair \& Shaver (2017), students find it difficult to grasp the complexity of sustaining intrinsic motivation and have presented a classroom exercise to help students better understand that complexity. Holbrook and Chappel (2018) have designed an in-class activity using a white board for the purpose of teaching Expectancy Theory of motivation which is considered a difficult topic for students to understand. Benson and Dresdow (2019) find that students have trouble in understanding the dynamics of motivation theories or deriving value from applying the theories to case analysis. They have suggested an exercise that facilitates personalising an experience and then applying motivation concepts. Afota and Robinson (2020) consider that teaching work motivation effectively can be challenging and have prescribed a role-play activity 
that induces students to compare different theories of motivation.

Use of clips from the movie Kung Fu Panda provides an additional option to teach work motivation concepts in the classroom in an effective way. Mischel (2018) has highlighted the advantages of teaching through the use of videos. Video based learning has proven to be a powerful reflection tool (Sablic et al., 2021).

The animation clips from the movie draw students' attention and make learning fun. Peer-learning through discussion of movie clips and students' reflection notes during a class brings about a cohesive learning experience. The movie is in English language, set in ancient China and used for teaching in India. This brings forth cultural inclusion in the teaching-learning process. The movie sheds insights on the importance of intrinsic motivation; how it was not sufficient for Po and why it needs to be supplemented with extrinsic motivation. It also highlights the ability of a trainer or manager to identify specific rewards with high valence for a specific person like food as a reward for Po. The movie focuses especially on the power of believing and the process of motivation involved in Po's journey from a state of low to high motivation.

\section{CONCLUSION}

The film dramatises the challenges faced by a trainer (akin to a manager in the corporate world) in the motivational process. It highlights the fact that each employee is different and has to be motivated differently. Different rewards have different valence for employees and it is the job of a manager to identify high valence rewards. The difference between intrinsic and extrinsic motivation and their complementary nature can be taught in the classroom with ease through the movie. It also helps in exemplifying the importance of managers' belief in their employees leading to Selffulfilling Prophecy. This highly engaging film brings all the three components of Vroom's Expectancy theory to life even for those not familiar with Kung Fu. It showcases the motivational concepts vividly and proves to be an interesting teaching resource.

\section{REFERENCES}

Afota, M.-C., \& Robinson, M. A. (2020). Mitigating Information Overload: An Experiential Exercise Using Role-Play to Illustrate and Differentiate Theories of Motivation. Management Teaching Review. https://doi.org/10.1177/2379298120933999

Bandura, A. (1977). Self-efficacy: Toward a unifying theory of behavioral change. Psychological Review, 84(2), 191-215. https://doi.org/10.1037/0033-295X.84.2.191

Benson, J., \& Dresdow, S. (2019). Delight and Frustration: Using Personal Messages to Understand Motivation. Management Teaching Review, (2), 112-122. https://doi.org/10.1177/2379298119851249

Biggs, M. (2013). Prophecy, Self-Fulfilling/Self-Defeating. In B. Kaldis (Ed.), Encyclopedia of Philosophy and the Social
Sciences. Sage Publications. https://doi.org/10.4135/9781452276052.n292

Blair, C. A., \& Shaver, K. G. (2017). Meaningful and Complex Work: An Exercise to Help Students Understand Intrinsic Motivation. Management Teaching Review, 4(1), 39-48. https://doi.org/10.1177/2379298117748568

Holbrook Jr., R. L., \& Chappell, D. (2018). Sweet Rewards: An Exercise to Demonstrate Process Theories of Motivation. Management Teaching Review, 4(1), 49-62. https://doi.org/10.1177/2379298118806632

Kung Fu Panda Awards. (n.d.). IMDb. Retrieved September 15, 2021, from https://www.imdb.com/title/tt0441773/awards

Leon-Perez, J. M., Medina, F. J., \& Munduate, L. (2011). Effects of self-efficacy on objective and subjective outcomes in transactions and disputes. International Journal of Conflict

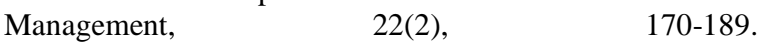
https://doi.org/10.1108/10444061111126693

Loomba, A.P.S., \& Karsten, R. (2019). Self-efficacy's role in success of quality training programmes. Industrial and $\begin{array}{lll}\text { Commercial } & \text { Training, } & \text { 51(1), }\end{array}$ https://doi.org/10.1108/ICT-06-2018-0058

Merton, R. K. (1948). The Self-Fulfilling Prophecy. The Antioch Review, 8, 193-210. https://dx.doi.org/10.2307/4609267

Mischel, L. J. (2018). Watch and Learn? Using EDpuzzle to Enhance the Use of Online Videos. Management Teaching Review, 4(3), 283-289. https://doi.org/10.1177/2379298118773418

Ryan, R. M., \& Deci, E. L. (2000). Self-determination theory and the facilitation of intrinsic motivation, social development, and well-being. The American Psychologist, 55(1), 68-78. https://doi.org/10.1037/0003-066X.55.1.68

Sablic, M., Mirosavljevic, A., \& Skugor, A. (2021). Video-Based Learning (VBL) - Past, Present and Future: an Overview of the Research Published from 2008 to 2019. Tech Know Learn, 26, 1061-1077. https://doi.org/10.1007/s10758-02009455-5

Stevenson, J., \& Osborne, M. (Directors). (2008). Kung Fu Panda [Film]. https://www.netflix.com/title/70075480

Vroom, V. (1964). Work and Motivation. Wiley. 